DOE/NV/11718-008

UC-702

OPERATED BY BECHTEL NEVADA

JANUARY 1996

\title{
ASSESSMENT OF PEN BRANCH DELTA AND CORRIDOR VEGETATION CHANGES USING MULTISPECTRAL SCANNER DATA 1992-1994
}

\section{MECE IVED \\ DEC 231996 \\ OSTI}

DWTAIBUTION OF THIS DOCUMENT IS UNLMMTEO

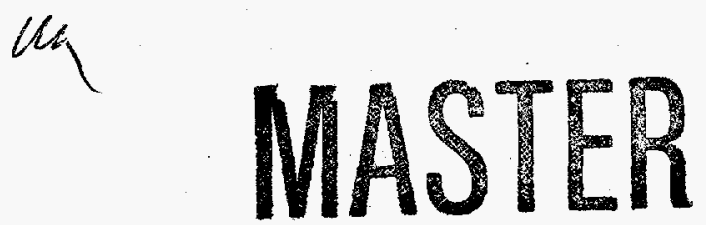




\section{DISCLAIMER}

This report was prepared as an account of work sponsored by an agency of the United Siates government. Neither the United States government nor an agency thereof, or any of their empleees, makes a warranty, express or implied, or assumes legal liability or responsibility for the actracy, completeness, or usefulness of any disclosed information, apparatus, product, or process or represents that its use would not infringe privately owned rights. Reference herein to a specific commercial product, process, or service by trade name, trademark, manufacturer, or otherwise does not necessarily constitute or imply an endorsement, recommendation, or favoring by the United States government or an agency thereof. The views and opinions of the authors expressed herein do not necessarily state or reflect those of the United States government or an agency thereof.

This report has been reproduced directly from the best available copy.

This report is available to DOE and DOE contractors from the Office of Scientific and Technical Information, P.O. Box 62, Oak Ridge, TN 37831. Call (615) $576-8401$ to obtain prices.

This report is available to the public from the National Technical Information Service, U.S. Department of Commerce, 5285 Port Royal, Springfield, VA 22161. 


\title{
ASSESSMENT OF PEN BRANCH DELTA AND CORRIDOR VEGETATION CHANGES USING MULTISPECTRAL SCANNER DATA 1992-1994
}

\author{
L. M. Christel \\ Project Scientist
}

\section{REVIEWED BY}

\section{Original Signed By}

L. R. Tinney, Manager

Spectral Imaging and

Geographic Information Systems

This Document is UNCLASSIFIED

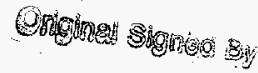

T. M. Hayes

Authorized Derivative Classifier

This work was performed by Bechtel Nevada under Contract Number DE-AC08-96NV11718 and by EG\&G/EM under Contract Number DE-AC08-93NV11265 with joint funding provided by the U.S. Department of Energy and Westinghouse Savannah River Company, operators of the Savannah River Site and Savannah River Technology Center at the time of the survey. 


\begin{abstract}
Airborne multispectral scanner data were used to monitor natural succession of wetland vegetation species over a three-year period from 1992 through 1994 for Pen Branch on the Savannah River Site in South Carolina. Image processing techniques were used to identify and measure wetland vegetation communities in the lower portion of the Pen Branch corridor and delta. When used with information from photographic, hydrologic, and ground-based phenological data sources of Pen Branch, MSS data provided a reliable means for monitoring medium- and large-scale changes in this diverse environment. The wetland vegetation changed from predominantly thermal-tolerant annual herbaceous species, such as Ludwigia spp., to persistent species that included Typha spp., followed by mixed persistent species with an extensive shrub-scrub invasion of willow (Salix spp.) and buttonbush (Cephalanthus spp.). Regeneration trends and remediation control practices, including herbicide applications, were also mapped. Findings from the study will be used to support decisions regarding remediation efforts following the cessation of cooling water discharge from a production reactor at the Department of Energy's Savannah River Site in South Carolina.
\end{abstract}




\section{CONTENTS}

Abstract

\section{Sections}

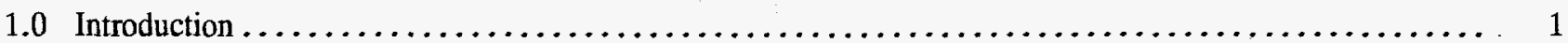

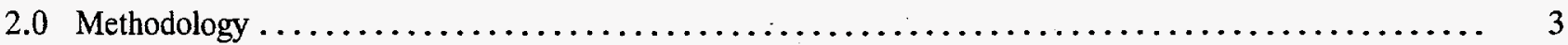

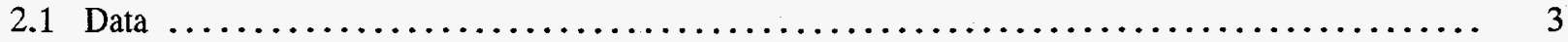

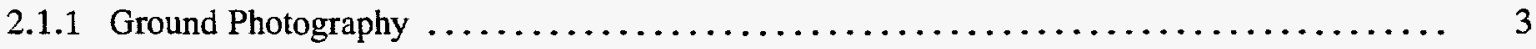

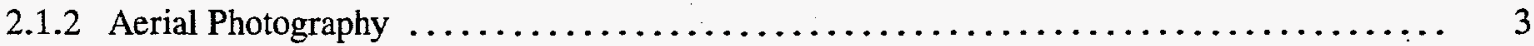

2.1.3 Daedalus AADS1260 and AADS1268 Multispectral Scanner Data $\ldots \ldots \ldots \ldots \ldots \ldots \ldots .6$

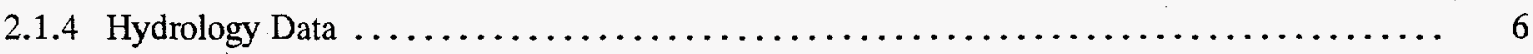

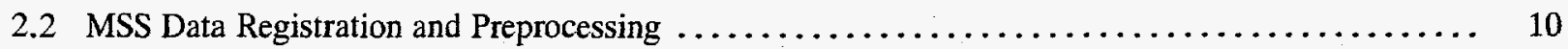

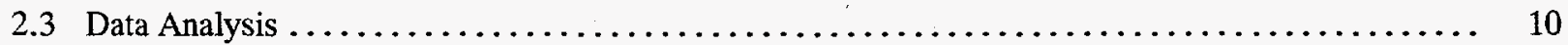

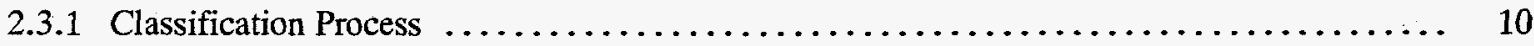

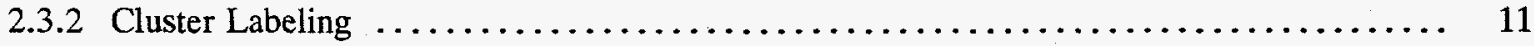

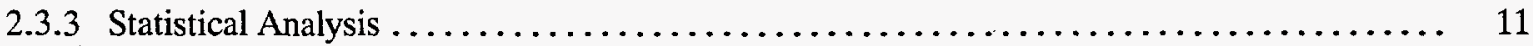

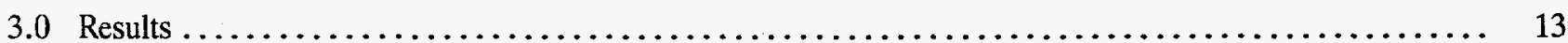

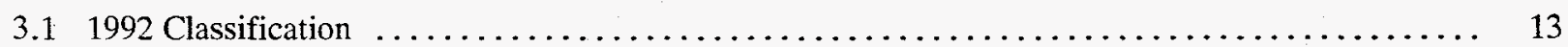

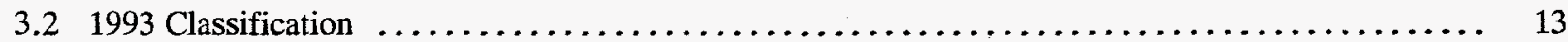

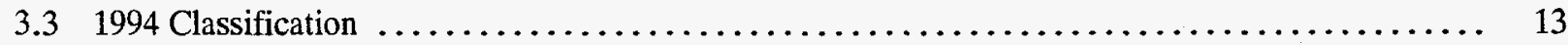

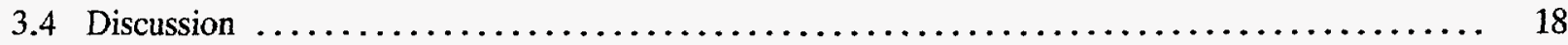

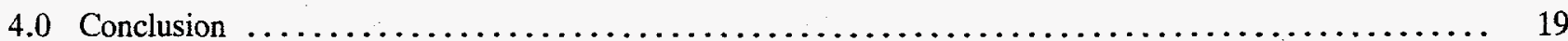

\section{Figures}

1 Selected SRS Facilities Are Shown in Red on This 1987 SPOT Panchromatic Image ............ 2

2 Red Circles on 1995 Daytime Thermal Image Show the Two Locations

Where Ground Photography Were Acquired $\ldots \ldots \ldots \ldots \ldots \ldots \ldots \ldots \ldots \ldots \ldots \ldots \ldots \ldots \ldots \ldots \ldots \ldots \ldots$

3 Traditional Flight Lines Used for Spring Missions at SRS $\ldots \ldots \ldots \ldots \ldots \ldots \ldots \ldots \ldots \ldots \ldots \ldots \ldots \ldots \ldots$

4 Pen Branch Flow Data from USGS Station Number $02197348 \ldots \ldots \ldots \ldots \ldots \ldots \ldots \ldots \ldots \ldots \ldots \ldots$

5 Savannah River Flow Data from USGS Station Number $02197320 \ldots \ldots \ldots \ldots \ldots \ldots \ldots \ldots \ldots \ldots$

6 Color Infrared Composite Images Used to Analyze Vegetation

Conditions in the Study Area . 


\section{DISCLAIMER}

Portions of this document may be illegible in electronic image products. Images are produced from the best available original document. 
8 Trends for Pen Branch Corridor Wetland Vegetation Classes for 1987 through 1994

9 Class Trends for Pen Branch Delta Wetland Vegetation Classes for 1987 through 1994

\section{Tables}

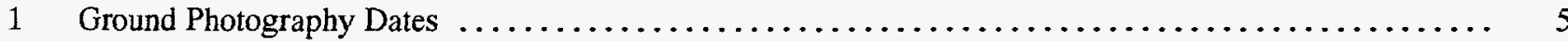

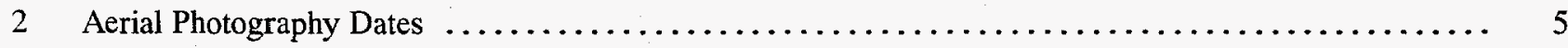

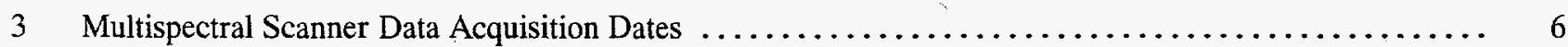

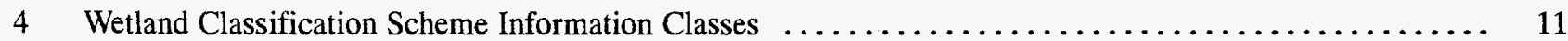

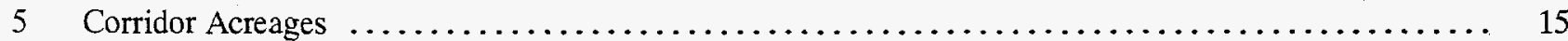

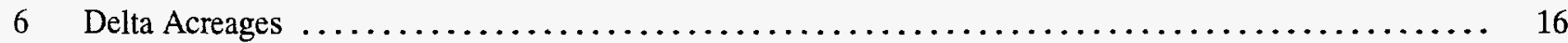

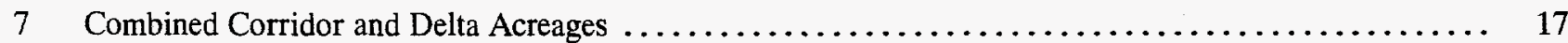

\section{Appendices}

A Comparison of Channel Wavelength and Spectral Response

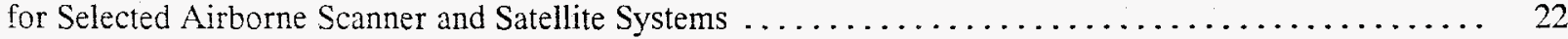

B Dates of MSS Data and Aerial and Ground Photography $\ldots \ldots \ldots \ldots \ldots \ldots \ldots \ldots \ldots \ldots \ldots \ldots \ldots \ldots \ldots$

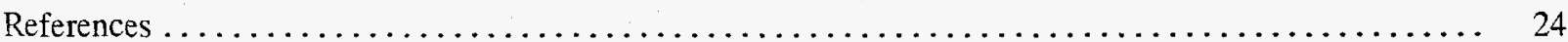




\subsection{INTRODUCTION}

The Savannah River Site (SRS) is owned by the U.S. Department of Energy and operated by Westinghouse Savannah River Company. In 1952, SRS was established as a defense nuclear production facility. Located near Aiken, South Carolina, SRS operated five production reactors and a coal-fired power plant on the 77700-hectare site. The facility used several on-site streams for discharging thermal effluent into the Savannah River. Figure 1 illustrates the locations of the predominant facilities at SRS, including the D-Area power plant and the C, K, L, P, and R reactors. Beginning in the 1950's, the corridor and delta of Pen Branch, portions of which are shown as the inset of Figure 1, served as a conduit for thermal effluent from K reactor. Until reactor operations ceased in 1988, flow rate for Pen Branch averaged between 10 and 11 cubic meters per second during reactor operations. This rate was about 10 times greater than the natural stream flow (Ruby et al., 1981). The average annual temperature of the effluent from $\mathrm{K}$ reactor reached 70 degrees Celsius (Ezra et al., 1986). The combination of increased water volume and temperature significantly altered the wetland vegetation patterns within the stream floodplain.

For the past decade, a variety of remotely sensed imagery, aerial and ground photography, and Geographic Information System (GIS) coverages have been acquired in support of environmental assessment activities at SRS. Remote sensing techniques have been used to address the issue of vegetation change detection within the Pen Branch corridor and delta during K reactor operation (Christensen et al., 1984; Tinney et al., 1986; Jensen et al., 1987). Other studies used aerial photographs (Tinney and Brewster, 1984), multispectral scanner (MSS) data (Christensen, 1987; Jensen et al., 1983; Jensen et al., 1986, 1987; Blohm, 1995; Burkhalter, 1991), and SPOT XS satellite imagery (Mackey, 1990, 1993) as sources for land cover analyses. Some of these data formats, when used individually, have limited spectral or spatial capabilities. When georegistered and used in an integrated format, multiple data sources create a data set that will support the type and quality of analyses required to identify wetland vegetation species distributions for site characterization. The characteristics of several sensor platforms are listed in Appendix A.

In 1986, an automated land cover database was designed to facilitate a more cohesive assessment of environmental issues at SRS. Classical photogrammetric techniques were used to interpret multi-date black and white and color infrared (CIR) aerial photography. Digital image interpretation techniques were used to extract the information available in satellite and MSS data. Field observations served as sources of ancillary data. Knowledgeable site personnel greatly contributed toward the integration and maintenance of accurate information in the SRS database or GIS. Also available are multi-date SPOT and MSS imagery in addition to digitized aerial photographs for sitewide or site-specific locations. These raster format data layers often serve 


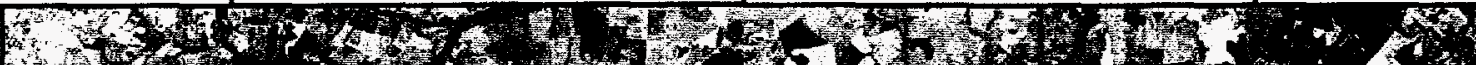
f

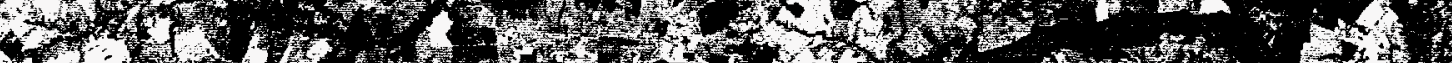

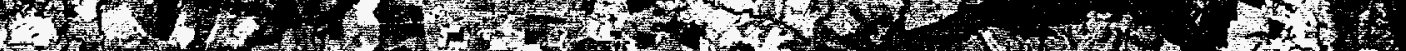

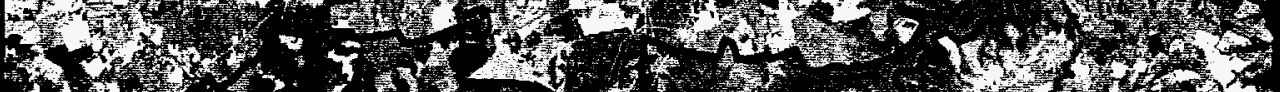

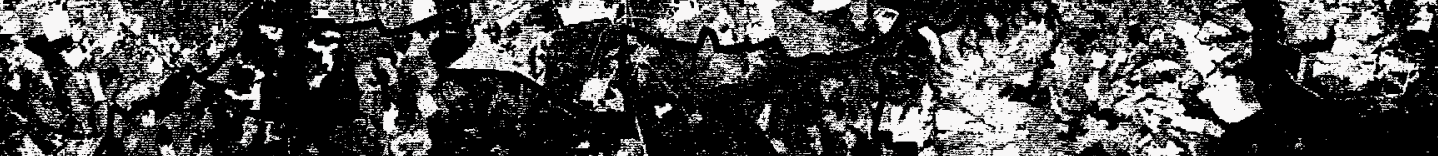

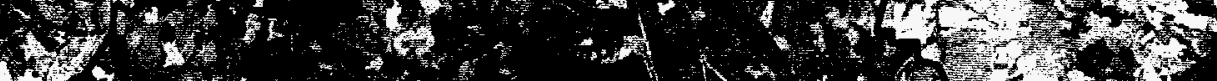

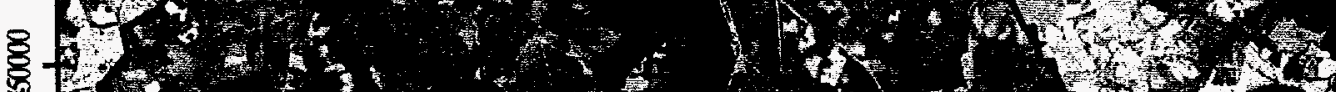
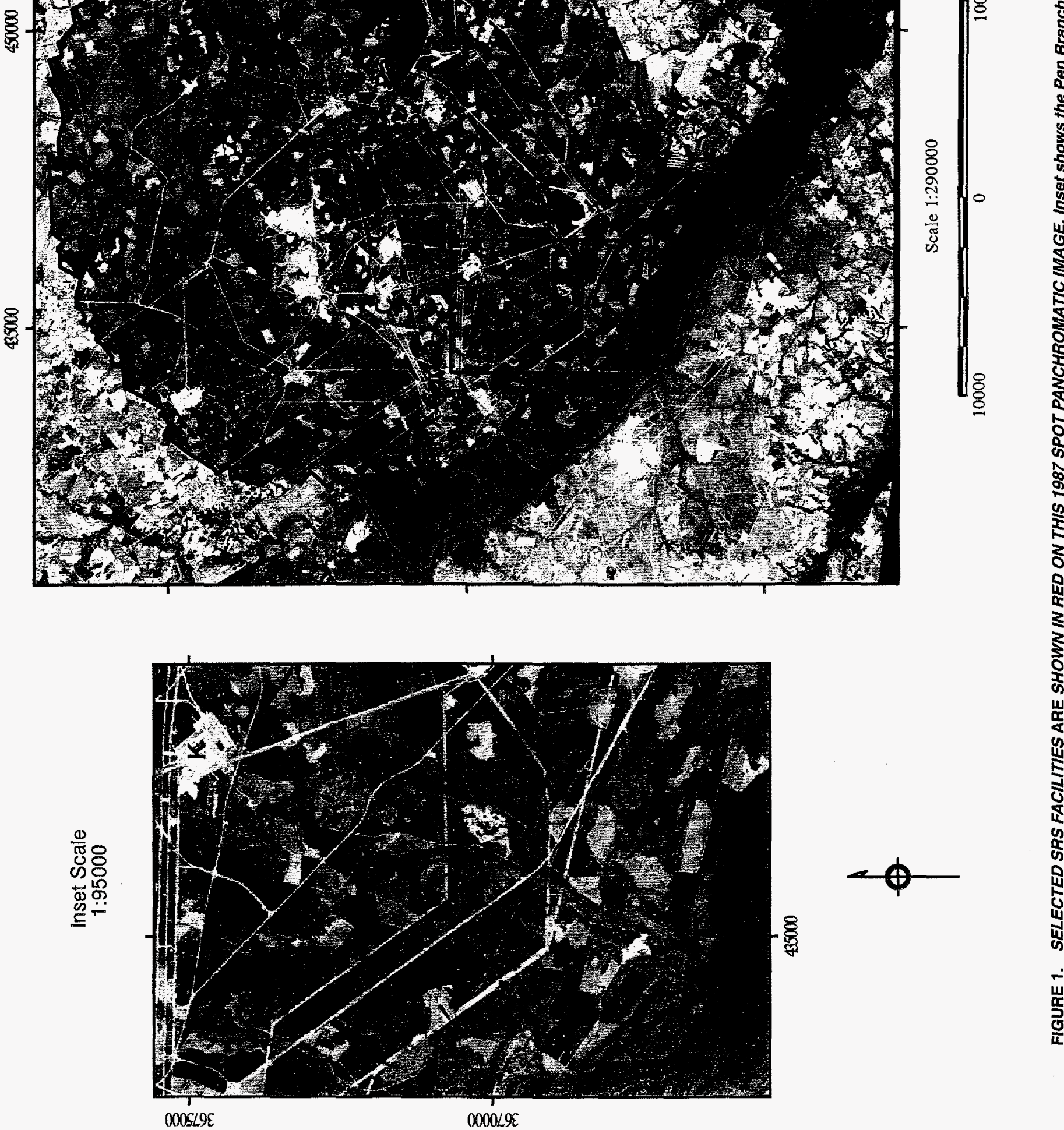
as source information from which the vector format data, in the form of line, point and polygon coverages, are derived. Since its inception, the SRS GIS has expanded to include multi-date radiological contour data, land cover, soils, roads, wells, historic and recent wetlands, and more specialized coverages such as Carolina Bays and archeological zones of interest (Cowen et al., 1995). All data used in this study were registered to Universal Transverse Mercator (UTM) Zone 17 using datum NAD27, Clarke 1866 spheroid to ensure compatibility with the existing SRS GIS. A quick reference to MSS data and aerial and ground photography dates used to support this study can be found in Appendix B.

\subsection{METHODOLOGY}

Vegetation trends in the Pen Branch corridor and delta from the years 1987 through 1991 are discussed in Blohm, 1995. The following discussion addresses the use of airborne MSS data for determining vegetation trends within the lower Pen Branch corridor and delta from 1992 through 1994. The portion of the corridor above the railroad bridge has been eliminated from this particular study due to the comparatively unchanging persistence of hardwoods in that section of the creek (Dulohery et al., 1995; Blohm, 1995).

\subsection{Data}

\subsubsection{Ground Photography}

In 1985, SRS initiated a series of monthly phenological observations during the summer and winter months and biweekly during the spring and fall months at the Pen Branch boardwalk and tail areas of the study sites. These areas are depicted in red circles on Figure 2 (Mackey, 1990,1993). Data on percent-leaf emergence and principle herbaceous wetland plants, such as relative height and emergent status, were recorded for both sites. Ground photography was taken at both locations to provide visual documentation of vegetation conditions and changes. Table 1 lists ground photography collection dates at these locations for years 1992 through 1994. Earlier dates and data are given in Mackey, 1993 and Blohm, 1995.

\subsubsection{Aerial Photography}

Vertical aerial photographs are usually acquired simultaneously. with the spring SRS airborne MSS missions. Aerial photography has also been acquired for SRS at other times throughout the year if requested. The photographs are usually collected at several altitudes, typically 4000 feet (approximately 1200 meters) and 


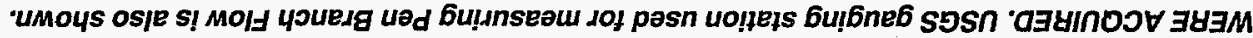

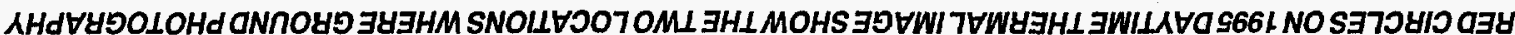

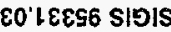

SเวเวW

$000 \mathrm{I}$
0

000tz:I ә[еos
OOOI

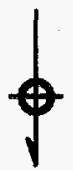

Cos\&Et

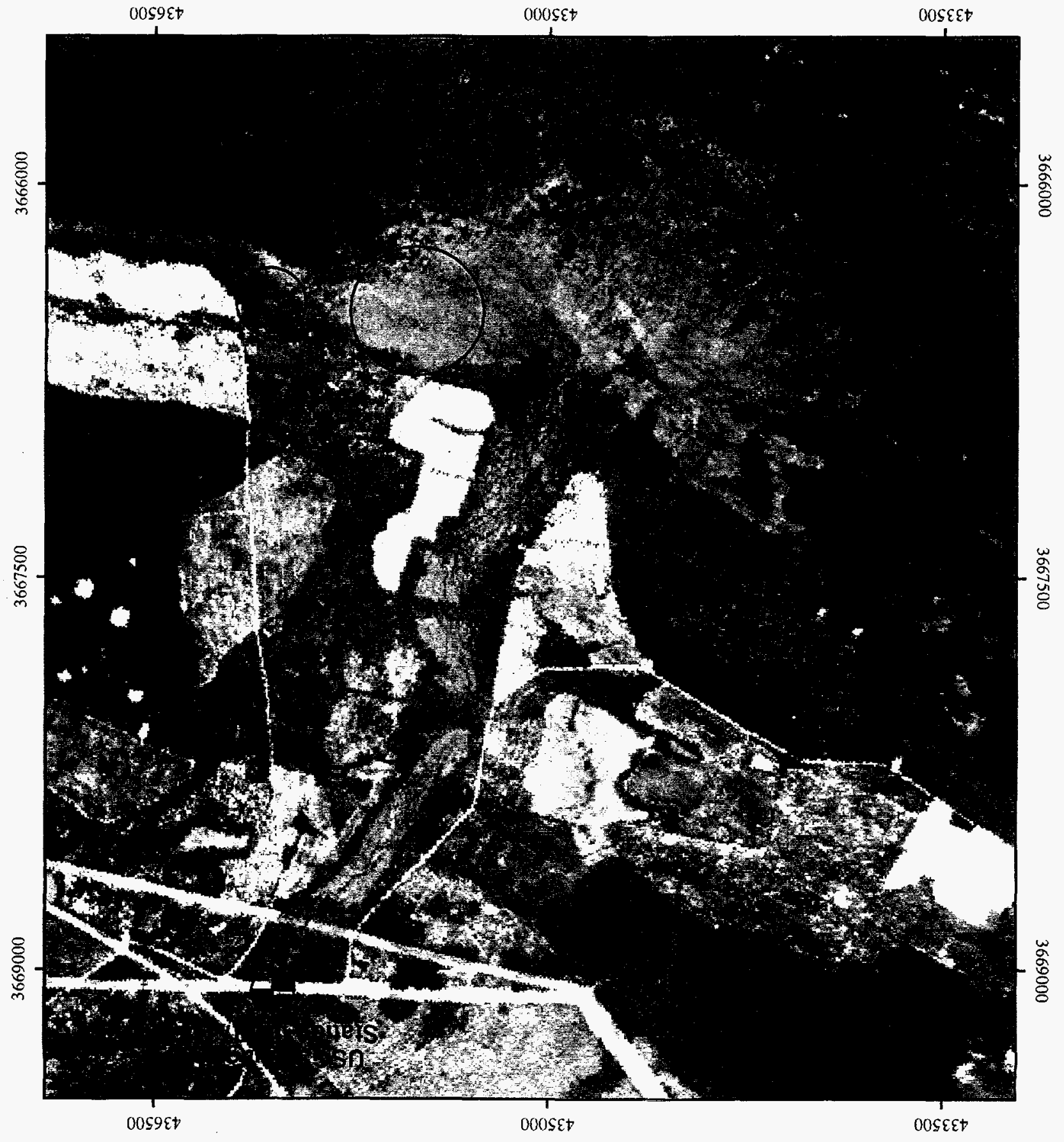


10000 feet (approximately 3000 meters) above ground level (AGL), resulting in large and small scale stereographic products. Under normal circumstances, both color and CIR film are used. In 1994, however, only color film was used due to an unaccessible camera port which prevented the use of both film types. The photography provides analysts with high-quality references for deriving vegetation classes, locating ground control points and reference panels, and comparing image classification results. Table 2 describes the aerial photography used to support this study. Altitudes are referenced to mean sea level (MSL). A comprehensive listing of the dates and types of film acquired for SRS by EG\&G/Energy Measurements can be found in Christel and Guber, 1994.

\begin{tabular}{|c|c|c|}
\hline \multicolumn{3}{|c|}{ Table 1. Ground Photography Dates } \\
\hline $\mathbf{1 9 9 2}$ & $\mathbf{1 9 9 3}$ & $\mathbf{1 9 9 4}$ \\
\hline 03 April & 03 March & 29 March \\
14, 15 April ${ }^{\mathrm{b}}$ & 16 March & 14 April \\
23 April & 15 April & 26 April \\
04 May & 30 April & 18 May \\
23 May & 13 May & 20 May \\
28 May & & \\
\hline
\end{tabular}

${ }^{a}$ Ground photography, except as noted in footnote $b$, with phenology data were provided by Halkard E. Mackey, $\mathrm{PhD}$, of the Environmental Sciences Section at SRS.

${ }^{b}$ Color ground photography archived at DOE RSL, Proof Books 7238 and 7239.

\begin{tabular}{|c|c|c|c|c|c|}
\hline Year & Date & Format & Film Type & $\begin{array}{c}\text { Altitude } \\
\text { MSL (feet) }\end{array}$ & $\begin{array}{l}\text { EG\&G Proof } \\
\text { Book Number }\end{array}$ \\
\hline 1992 & $\begin{array}{l}23 \text { April } \\
02 \text { May } \\
04 \text { May }\end{array}$ & $\begin{array}{l}\text { Vertical } \\
\text { Vertical } \\
\text { Vertical }\end{array}$ & $\begin{array}{l}\text { CIR } \\
\text { CIR } \\
\text { CIR }\end{array}$ & $\begin{array}{l}10100 \\
10100 \\
10100\end{array}$ & $\begin{array}{l}7233 \\
7234 \\
7735\end{array}$ \\
\hline 1993 & $\begin{array}{l}17 \text { May } \\
19 \text { May }\end{array}$ & $\begin{array}{l}\text { Vertical } \\
\text { Vertical }\end{array}$ & $\begin{array}{l}\text { Color, CIR } \\
\text { Color, CIR }\end{array}$ & $\begin{array}{c}10000 \\
10200,4200\end{array}$ & $\begin{array}{l}7404,7405 \\
7406,7407\end{array}$ \\
\hline 1994 & $\begin{array}{l}\text { 14 April } \\
\text { 14, 15 April } \\
\text { 15,17 April } \\
\text { 17, 18 April } \\
\text { 18 April }\end{array}$ & $\begin{array}{l}\text { Vertical } \\
\text { Oblique } \\
\text { Oblique } \\
\text { Oblique } \\
\text { Vertical }\end{array}$ & $\begin{array}{l}\text { Color } \\
\text { Color } \\
\text { Color } \\
\text { Color } \\
\text { Color }\end{array}$ & $\begin{array}{l}10300 \\
10300 \\
10300 \\
10300 \\
10300\end{array}$ & $\begin{aligned} 7710 \\
7718 \\
7722 \\
7719,7720,7721 \\
7716\end{aligned}$ \\
\hline
\end{tabular}

${ }^{a}$ Aerial oblique shots were acquired with $35 \mathrm{~mm}$ cameras. Vertical aerial photography was acquired with $9 \times 9$ large-format RC-20 (1992) and Wild RC-10 (1993, 1994) cameras. 


\subsubsection{Daedalus AADS1260 and AADS1268 Multispectral Scanner Data}

The Daedalus AADS1260 and AADS1268 are capable of collecting 10 channels of spectral data (0.42-2.35 micrometers) and two channels of thermal infrared data (8.30-13.40 micrometers). Bandwidths for the thermal channel are identical, but different gain settings are usually employed to compensate for site-specific characteristics. The scanners also support variable scan rates to ensure continuous coverage at different altitudes relative to ground speed. Table 3 shows the dates when MSS data used for this three-year study were collected. The AADS1268 is normally used for SRS missions, but it was not available for use in 1992. Figure 3 shows the flight lines that have been traditionally flown for SRS missions. Flying altitudes for any or all of these have been 2000,4000 , and 10000 feet AGL depending on mission requirements. Refer to Appendix A for a breakout of channel bandwidths and more information regarding the Daedalus AADS1260 and AADS1268.

\subsubsection{Hydrology Data}

U.S. Geologic Survey (USGS) hydrology data for Pen Branch and Savannah River (Bennett, 1993, 1994; Cooney, 1995) were used to determine if hydrologic events influenced spring vegetation species distributions in the Pen Branch corridor and delta. Pen Branch flow rates are recorded at the SRS Road A13.2 gauge station and shown in red in Figure 2. Savannah River flow rates above SRS are recorded at the Jackson gauge station. The Jackson gauge does not record flow data during periods of extreme flooding (greater than 22000 cubic feet per second [623 cubic meters per second]). Alternatively, during flood events, river flow rates from the following day at the 301 Bridge gauge station located down-river are used to estimate Savannah River flow rates at SRS (Mackey, 1993). Figures 4 and 5 show flow rates in the Pen Branch corridor and Savannah River at SRS for 1992 through 1994, respectively.

\begin{tabular}{|c|c|c|c|}
\hline \multicolumn{2}{|c|}{ Table 3. Multispectral Scanner Data Acquisition Dates } \\
\hline Year & Date & Time & $\begin{array}{c}\text { Altitude AGL } \\
\text { (feet) }\end{array}$ \\
\hline 1992 & 23 April & 1333 & $10000^{\mathrm{a}}$ \\
1993 & 22 April & 1403 & 10000 \\
1994 & 18 April & 1343 & 10000 \\
\hline
\end{tabular}

a MSS data flown at $10000 \mathrm{ft}$ AGL resulted in a pixel size of $7.6 \mathrm{~m} \times 7.6 \mathrm{~m}$. 


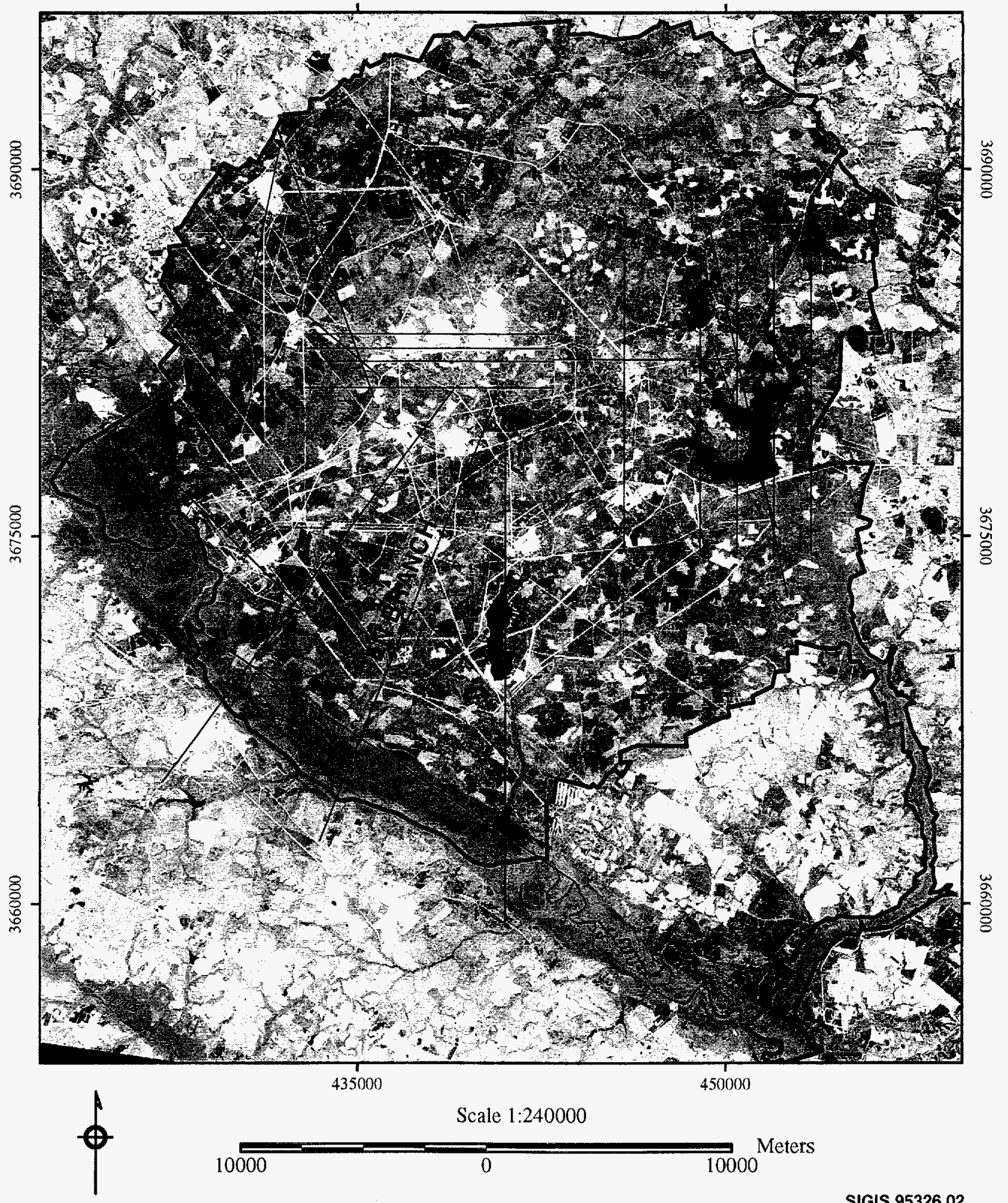

FIGURE 3. TRADITIONAL FLIGHT LINES USED FOR SPRING MISSIONS AT SRS 


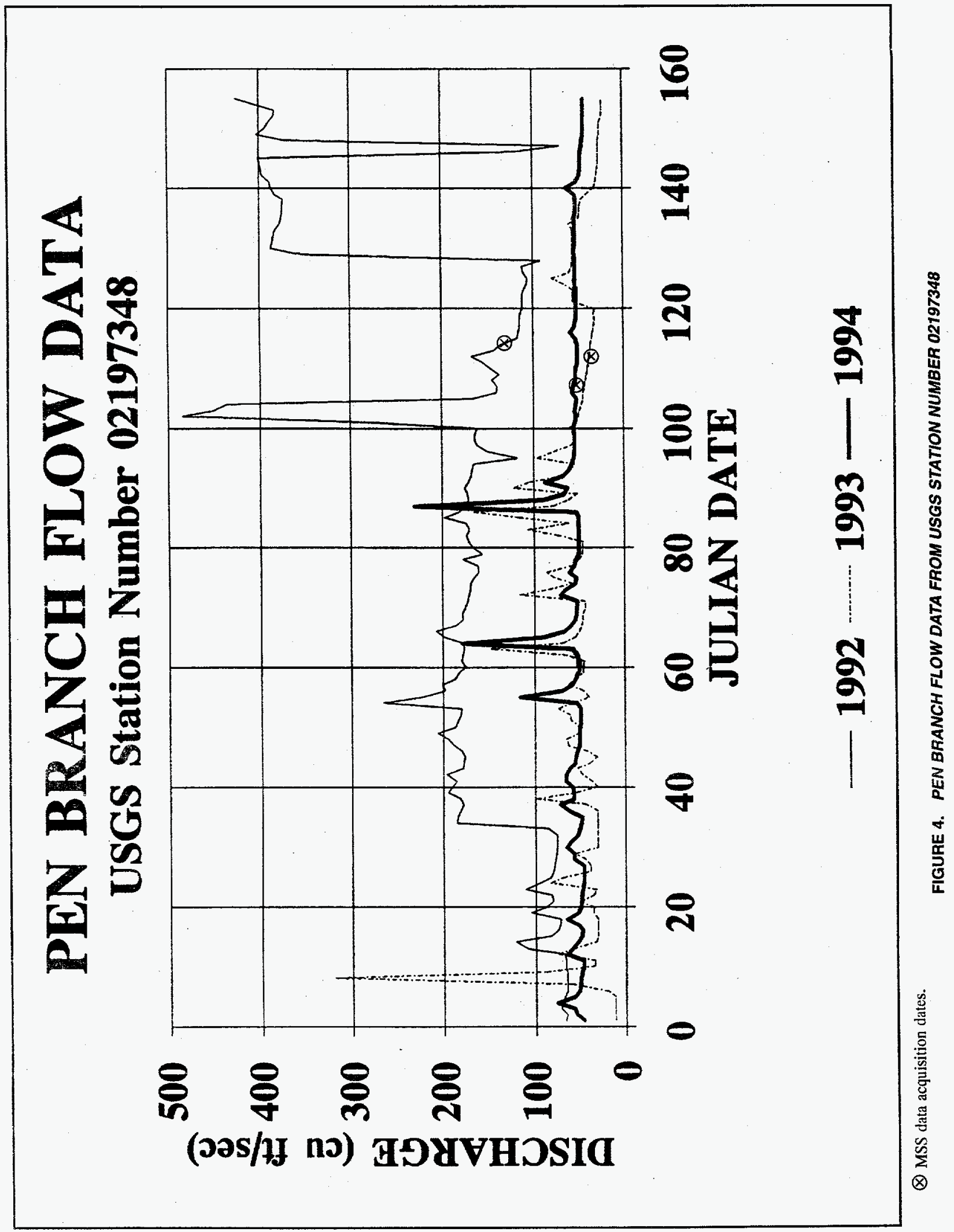




\section{SAVANNAH RIVER FLOW USGS Station Number 02197320}

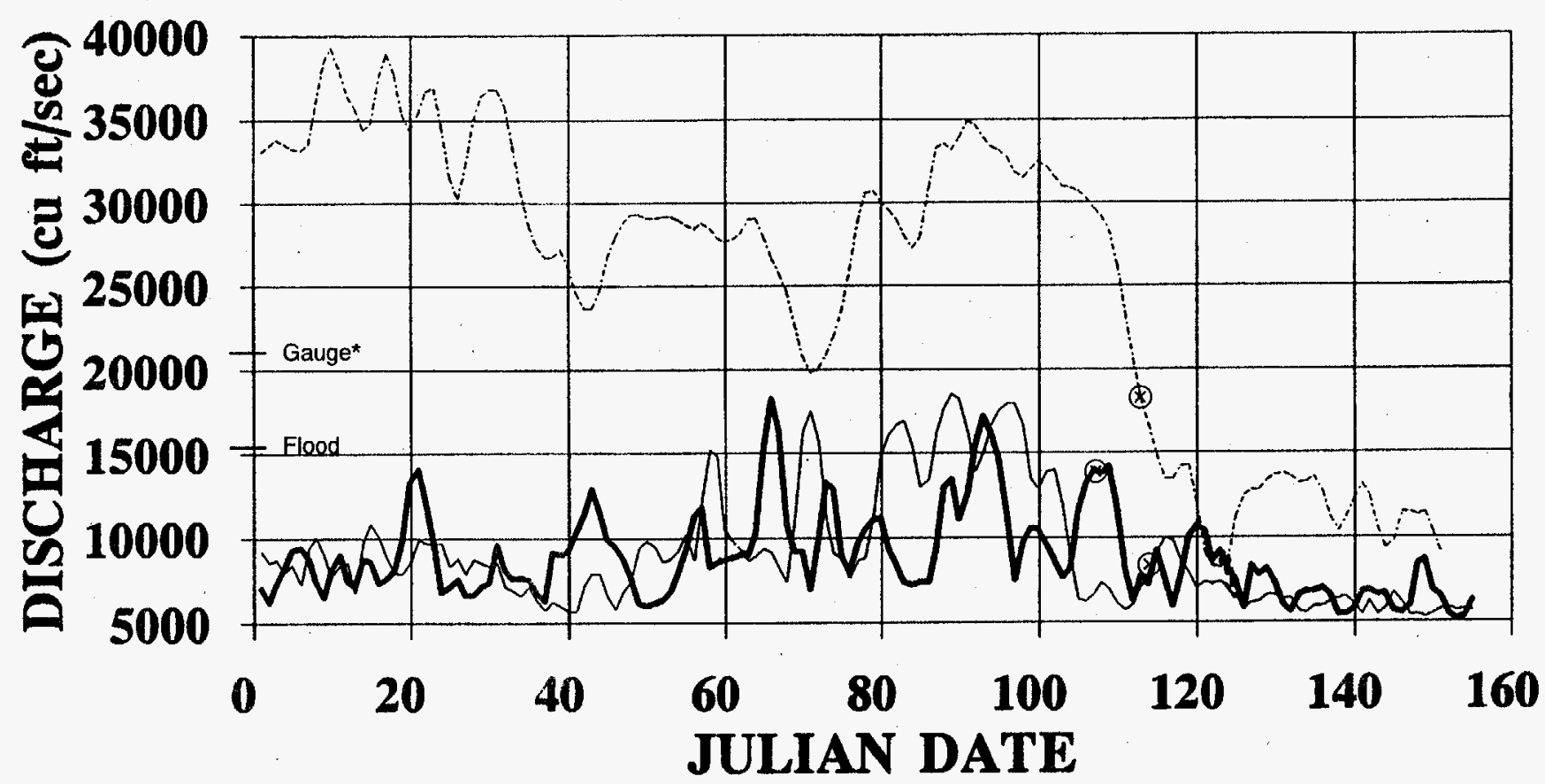

$$
-1992-1993-1994
$$

@ MSS data acquisition dates.

* Flow data above gauge level are interpolated from the 301 Bridge gauage station. 


\subsection{MSS Data Registration and Preprocessing}

Over the term of the Pen Branch change detection study from 1987 through 1994, a variety of data registration techniques were used to incorporate the different data types used in temporal analysis. Earlier studies that made use of aerial photography and satellite imagery relied on simple linear transformation equations for registration. Because of the inherent geometric distortion associated with airborne multispectral scanners, more robust algorithms are often required to correct MSS data (Lillesand and Kiefer, 1987). Flight conditions greatly influence the extent of distortion for which corrections are needed. A technique known as finite element registration has been used for achieving acceptable registration accuracies in spite of severe nonlinear distortion attributable to aircraft motion (Blohm, 1995). MSS data acquisition of the Pen Branch flight lines for the three years (1992-1994) encompassed in this report were only mildly effected by scannerand aircraft-related distortions. Second order polynomial transformation equations were required to georegister the 1992 and 1993 data while a simple affine transformation was all that was needed to co-register the 1994 data. Image processing tools available in PCI's EasiPace software, Version 5.1 (PCI, 1992), were used to support the preprocessing of the data. The existing SRS GIS is maintained in the UTM projection for Zone 17. Total RMS errors were kept below 10 feet (3.048 meters). The registered data were compared to the 1987 Pen Branch classified image (Blohm, 1995) that was subsequently used as the mask to extract the Pen Branch corridor and delta study areas for the analysis.

\subsection{Data Analysis}

Following the data registration process, the twelve channels of information for each of the three image files were quality checked and reviewed for informational content. Previous analyses of the Pen Branch corridor and delta (Blohm, 1995) have revealed the need to separate the corridor from the delta (during the classification process) to avoid confusion between old field species in the corridor and persistent emergent species, typically cattails, in the delta. Consequently, the mask created using the 1987 classified image was separated at the corridor/delta transition area. The resulting segments were used to select identical classification regions for each year's analysis.

\subsubsection{Classification Process}

The DECORR routine in EasiPace (PCI, 1992) was used for each date to identify which of the 10 spectral channels were highly correlated in an effort to identify and remove redundant information from the data sets. 
After channel selections were made, the unsupervised clustering algorithm ISOCLUS was used to identify spectral classes in each scene. Several iterations of ISOCLUS were required for each data set to optimize the routine's input parameters for improved class separability.

Table 4 lists the wetland classification scheme used for this study. The scheme was based on those used for previous studies of Pen Branch (Jensen, et al. 1986; Christensen, 1987; Blohm, 1995).

Figure 6 shows the unregistered MSS CIR composite images used to visually analyze vegetation conditions in the study area. Daedalus AADS1260 MSS Channels 8, 5, and 3 were used as R, G, and B to generate the 1992 image on the left. Daedalus AADS1268 MSS Channels 7, 4, and 2 were used as R, G, and B to generate the 1993 and 1994 images.

\subsubsection{Cluster Labeling}

The cluster labeling process was conducted with the assistance of SRS personnel, ground phenology, and aerial photographs. When information classes were determined for each data set, the AGGREG routine was used to aggregate spectral classes into information classes.

\subsubsection{Statistical Analysis}

After the information classes were aggregated, the area of each class was calculated. Data were presented for the lower corridor and delta sections both separately and as one entity and compared to previous findings

\section{Table 4. Wetland Classification Scheme Information Classes}

Hardwood

Cypress

Water

Cattails

Shrub-Scrub/Willow

Ludwigia

Mudflat

Duckweed

Bare Soil

Old Field

Parrot-Feather

Wetland Vegetation 

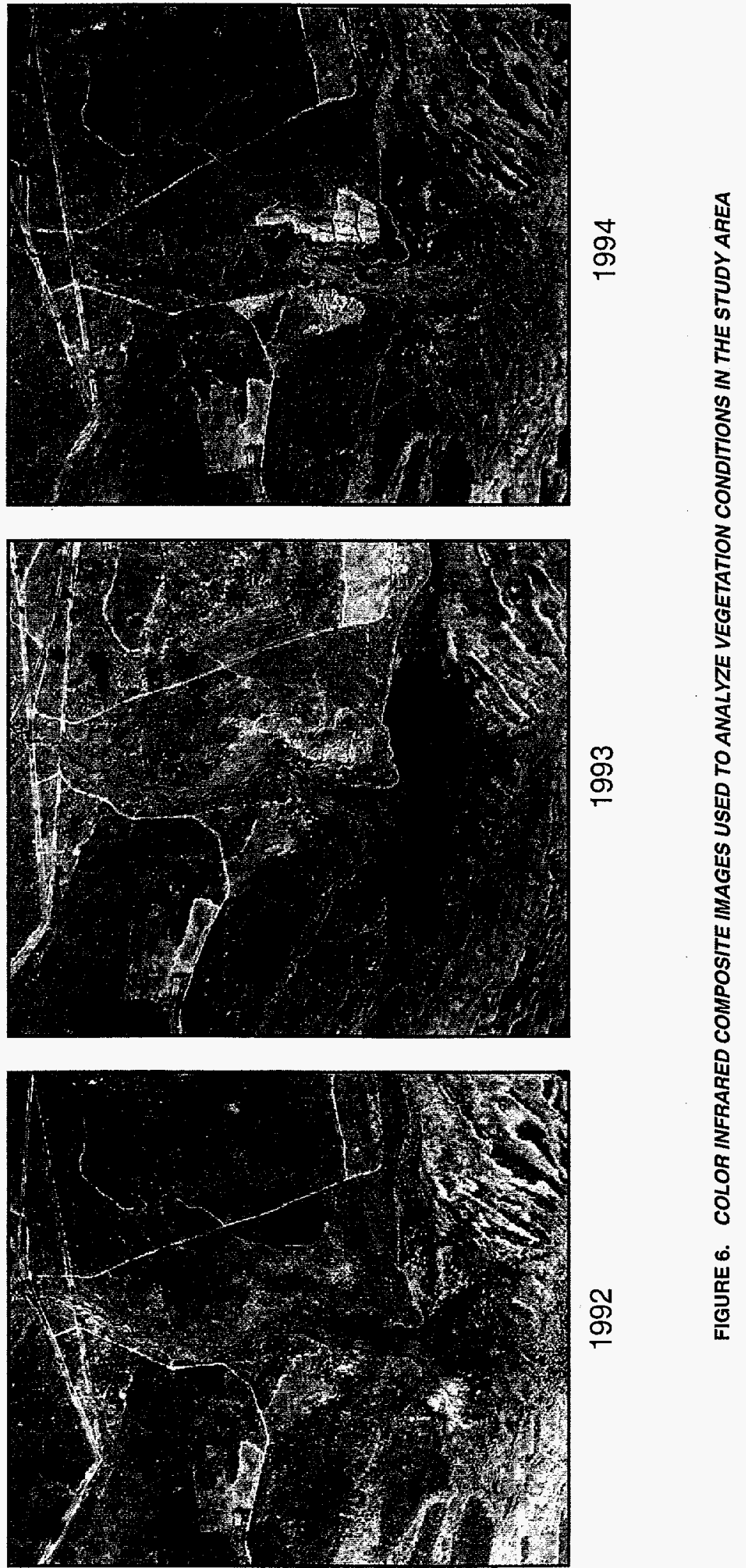

学 
(Blohm, 1995). Because of the herbicide treatment in the lower corridor, change-pair analyses were not performed for this study.

\subsection{RESULTS}

Classification results for each year are presented in Figure 7 and discussed in the following sections. As anticipated, unsupervised classification results for all three years indicated that confusion existed between cypress in the delta and shrub-scrub/willow in the corridor and required the use of the corridor and delta masks established in Blohm, 1995. The reader is reminded that acreage totals for the lower Pen Branch corridor will be smaller than those reported in Blohm, 1995, due to the decision to limit the corridor study area to south of SRS Road A13.2. Please refer to Tables 5 and 6 for area statistics on corridor and delta acreage, respectively. Table 7 lists the combined corridor and delta acreages.

\subsection{Classification}

In both the corridor and delta, results from the cluster labeling showed that parrot-feather and wetland vegetation had increased over the previous year. In the delta, the hardwood, cypress, and duckweed classes increased while water, cattails, and shrub-scrub/willow classes declined. Water and cattail classes also decreased in the corridor, but the shrub-scrub/willow acreage increased. Hardwood acreage in the corridor is not compared to the previous year due to the change in the study area. Neither mud flat or bare soil classes were present in the delta, nor were cattails present in the corridor throughout the three-year study. Bare soil in the corridor had decreased from the previous year.

\subsection{Classification}

In the delta, hardwood, cypress, water, shrub-scrub/willow, and wetland vegetation class acreages increased from the previous year while cattails, duckweed, and parrot-feather classes decreased. In the corridor, hardwood, water, and bare soil classes increased while shrub-scrub/willow, parrot-feather, and wetland vegetation classes decreased.

\subsection{Classification}

Except for the water and shrub-scrub/willow classes, all class acreages increased in the delta. Conversely, all class acreages except old field decreased in the corridor. Class acreages in the corridor were affected by 


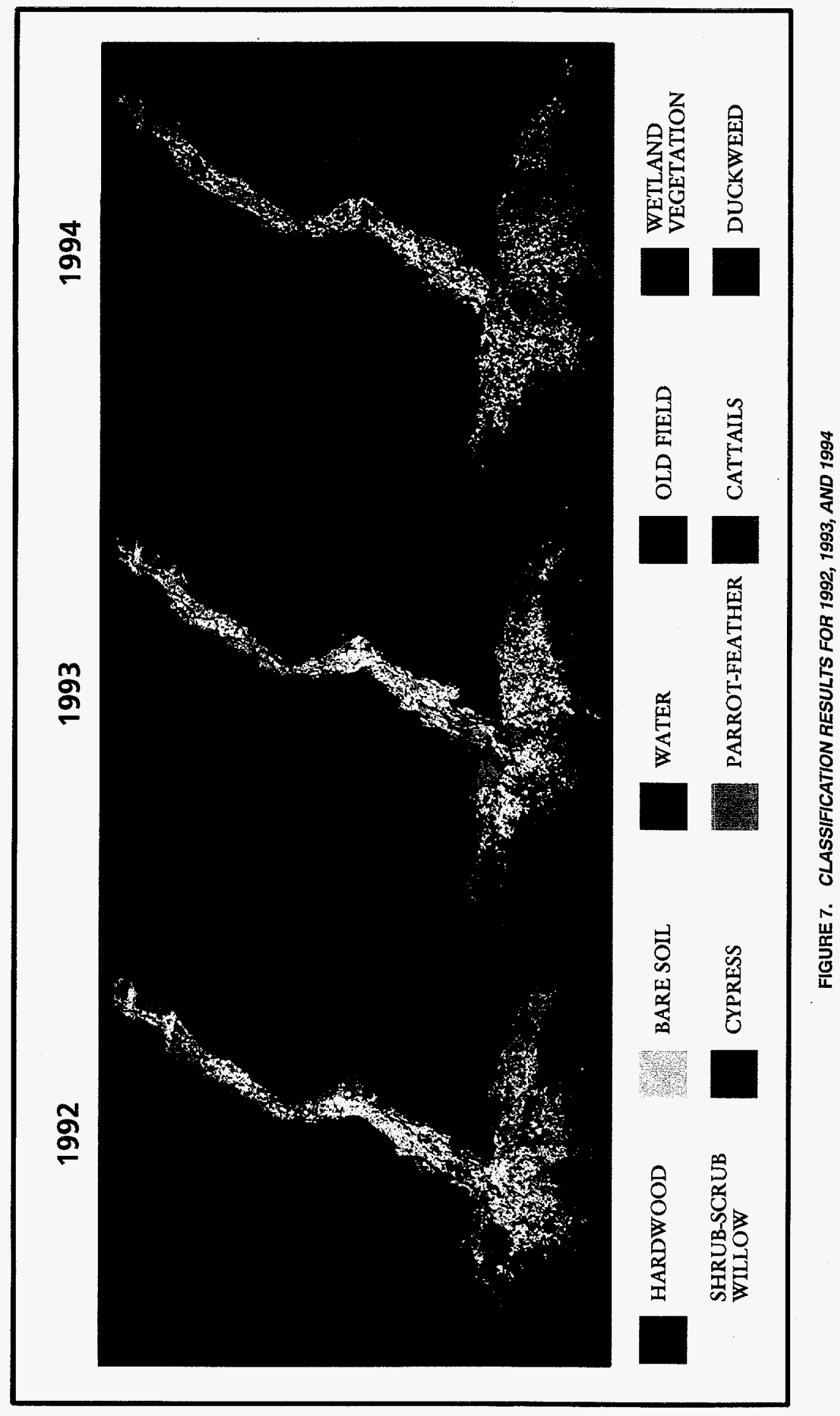




\begin{tabular}{|c|c|c|c|c|c|c|c|c|}
\hline \multirow[b]{2}{*}{ Class } & \multicolumn{5}{|c|}{ Total } & \multicolumn{3}{|c|}{ Lower* } \\
\hline & 1987 & 1988 & 1989 & 1990 & 1991 & 1992 & 1993 & 1994 \\
\hline Hardwood & 105.05 & 107.08 & 130.27 & 137.82 & 161.86 & 8.59 & 25.11 & 16.41 \\
\hline Cypress & 0 & 0 & 0 & 0 & 0 & 0 & 0 & 0 \\
\hline Water & 115.76 & 37.83 & 41.86 & 42.64 & 33.51 & 25.37 & 29.20 & 24.32 \\
\hline Cattails & 0 & 0 & 0 & 0 & 1.65 & 0 & 0 & 0 \\
\hline Shrub-Scrub/Willow & 33.96 & 25.91 & 52.36 & 46.88 & 55.10 & 65.84 & 55.83 & 49.93 \\
\hline Ludwigia & 0 & 32.03 & 23.84 & 18.22 & 0 & 0 & 0 & 0 \\
\hline Mud Flat & 14.64 & 69.38 & 24.64 & 28.08 & 20.02 & 0 & 0 & 0 \\
\hline Duckweed & 0.95 & 0 & 0 & 0 & 0 & 0 & 0 & 0 \\
\hline Bare Soil & 4.03 & 2.15 & 1.41 & 0.74 & 2.23 & 1.57 & 4.74 & 3.28 \\
\hline Old Field & 0 & 0 & 0 & 0 & 0 & 0 & 0 & 31.04 \\
\hline Parrot-Feather & 0 & 0 & 0 & 0 & 0 & 10.41 & 0 & 0 \\
\hline Wetland Vegetation & 0 & 0 & 0 & 0 & 0 & 35.16 & 33.88 & 24.35 \\
\hline Total & 274.39 & 274.38 & 274.38 & 274.38 & 274.37 & 146.94 & 148.76 & 149.33 \\
\hline
\end{tabular}

${ }^{*}$ Study area includes corridor south of the A13.2 Bridge for these years. 


\begin{tabular}{|l|c|c|c|c|c|c|c|c|c|}
\hline \multicolumn{10}{|c|}{ Table 6. Delta Acreages (acres) } \\
\hline \multicolumn{1}{|c|}{ Class } & $\mathbf{1 9 8 7}$ & $\mathbf{1 9 8 8}$ & $\mathbf{1 9 8 9}$ & $\mathbf{1 9 9 0}$ & $\mathbf{1 9 9 1}$ & $\mathbf{1 9 9 2}$ & $\mathbf{1 9 9 3}$ & $\mathbf{1 9 9 4}$ \\
\hline Hardwood & 0 & 0.10 & 1.36 & 0.44 & 0.89 & 1.83 & 2.22 & 2.52 \\
Cypress & 0 & 16.73 & 25.39 & 22.09 & $0^{\mathrm{a}}$ & 25.97 & 34.66 & 50.21 \\
Water & 114.54 & 95.53 & 48.28 & 23.50 & 49.35 & 38.33 & 46.04 & 43.37 \\
Cattails $^{b}$ & 16.17 & 0 & 12.64 & 44.36 & 97.92 & 57.35 & 42.62 & 56.63 \\
Shrub-Scrub/Willow & 7.58 & 14.40 & 17.91 & 19.95 & $83.99 \mathrm{a}$ & 49.80 & 58.45 & 25.68 \\
कudwigia & 76.02 & 102.97 & 128.74 & 112.12 & 0 & 0 & 0 & 0 \\
Mud Flat & 0 & 0 & 0 & 0 & 0 & 0 & 0 & 0 \\
Duckweed & 20.00 & 4.59 & 0 & 0 & 2.13 & 4.76 & 0 & 0 \\
Bare Soil & 0 & 0 & 0 & 0 & 0 & 0 & 0 & 0 \\
Old Field & 0 & 0 & 0 & 0 & 0 & 0 & 0 & 4.26 \\
Parrot-Feather & 0 & 0 & 0 & 0 & 0 & 26.35 & 0 & 0 \\
Wetland Vegetation & 0 & $\mathbf{0}$ & 0 & 0 & 0 & 31.84 & 49.70 & 53.37 \\
\hline \multicolumn{2}{r|}{ Total } & $\mathbf{2 3 4 . 3 1}$ & $\mathbf{2 3 4 . 3 2}$ & $\mathbf{2 3 4 . 3 2}$ & $\mathbf{2 2 2 . 4 6}$ & $\mathbf{2 3 4 . 2 8}$ & $\mathbf{2 3 6 . 2 3}$ & $\mathbf{2 3 3 . 6 9}$ & $\mathbf{2 3 6 . 0 4}$ \\
\hline
\end{tabular}

a Cypress and shrub-scrub/willow probably confused in 1991.

${ }^{b}$ After 1991 cattails and areas of wetland vegetation sorted into two classes. 


\begin{tabular}{|c|c|c|c|c|c|c|c|c|}
\hline \multirow[b]{2}{*}{ Class } & \multicolumn{5}{|c|}{ Total Corridor and Delta } & \multicolumn{3}{|c|}{ Lower Corridor and Delta } \\
\hline & 1987 & 1988 & 1989 & 1990 & 1991 & 1992 & 1993 & 1994 \\
\hline Hardwood & 105.05 & 107.18 & 131.63 & 138.26 & 162.75 & 10.42 & 27.33 & 18.93 \\
\hline Cypress & 0 & 16.73 & 25.39 & 22.09 & $0^{\mathrm{a}}$ & 25.97 & 34.66 & 50.21 \\
\hline Water & 230.30 & 133.36 & 90.14 & 66.14 & 82.86 & 63.70 & 75.24 & 67.69 \\
\hline Cattails $^{\mathrm{b}}$ & 16.17 & 0 & 12.64 & 44.36 & 99.57 & 57.35 & 42.62 & 56.63 \\
\hline Shrub-Scrub/Willow & 41.54 & 40.31 & 73.30 & 66.83 & $139.0^{\mathrm{a}}$ & 115.64 & 114.28 & 75.61 \\
\hline Ludwigia & 76.02 & 135.00 & 152.58 & 130.34 & 0 & 0 & 0 & 0 \\
\hline Mud Flat & 14.64 & 69.38 & 24.64 & 28.08 & 20.02 & 0 & 0 & 0 \\
\hline Duckweed & 20.95 & 4.59 & 0 & 0 & 2.13 & 4.76 & 0 & 0 \\
\hline Bare Soil & 4.03 & 2.15 & 1.41 & 0.74 & 2.23 & 1.57 & 4.74 & 3.28 \\
\hline Old Field & 0 & 0 & 0 & 0 & 0 & 0 & 0 & 35.30 \\
\hline Parrot-Feather & 0 & 0 & 0 & 0 & 0 & 36.76 & 0 & 0 \\
\hline Wetland Vegetation & 0 & 0 & 0 & 0 & 0 & 67.0 & 83.58 & 77.72 \\
\hline Total & 508.70 & 508.70 & 508.70 & 496.84 & 506.52 & 383.17 & 382.45 & 385.37 \\
\hline
\end{tabular}

a Cypress and shrub-scrub/willow probably confused in 1991 .

${ }^{b}$ After 1991 cattails and areas of wetland vegetation sorted into two classes. 
the application of the herbicide Rodeo. The application areas in the lower corridor can be seen as solid, dark fields interrupted only by control plots in the 1994 CIR image shown in Figure 6. The Rodeo affected areas of the shrub-scrub/willow, including some mature willow that may have been included in the hardwood class acreages in previous years. Red maple survived the treatment (Dulohery et al., 1995).

\subsection{Discussion}

Figures 8 and 9 show the class trends for the Pen Branch corridor and delta between 1987 and 1994, respectively. The cypress class is exhibiting an upward trend. The hardwood and shrub-scrub/willow classes were gaining acreage until the herbicide treatment during the winter of 1993-1994 (Dulohery et al., 1995). Old field acreage in the corridor has increased, possibly due to the absence of the higher water-flow conditions. Mud flats are no longer represented and bare soil, which has a small representation, is fluctuating. These two classes are probably responding to decreased water flow in the corridor. The additional wetland vegetation class shown in Tables 5,6, and 7 also exhibit fluctuations in acreage estimates and these apparent changes may be attributable to confusion of various wetland classes with cattails in the delta. Furthermore, cattail acreage fluctuation in the delta may be partly due to changes in water flow in the delta in addition to the class confusion between sparse cattails and old field species seen in previous years (Wike et al., 1994). Duckweed and parrot-feather, which are indicator species for wet conditions, have not been represented since 1992.

When looking at overall trends for this three-year study, it is helpful to understand the influence that water flow has on class acreages throughout the corridor and delta (Wike et al., 1994). Figures 3 and 4 show the water levels for the three acquisition dates. The corridor had high water levels in 1992 while water levels in the delta were high in 1993. Water levels during the previous years' summer months play an important role in class representations the following spring (Mackey, 1990). As an example, $\mathrm{K}$ reactor tests during 1991 and increased rainfall during the early part of 1992 resulted in elevated flow through the corridor. These conditions, coupled with increased flow in the Savannah River during the summer of 1992, resulted in extremely wet conditions. This may account for the decrease in cattails and shrub-scrub/willow as well as the increase in duckweed and parrot-feather. The presence of these two latter species would reflect conditions of slow-moving, deep open water.

Rainfall throughout early 1993 resulted in flood conditions in the Pen Branch delta during MSS data acquisition (Figure 5). The increased water acreage and extremely wet conditions made classification efforts difficult.

Conditions for 1994 were comparatively stable, but vegetation trends in the corridor were affected by the herbicide treatment. The removal of some mature willow may have had an influence on hardwood acreage 


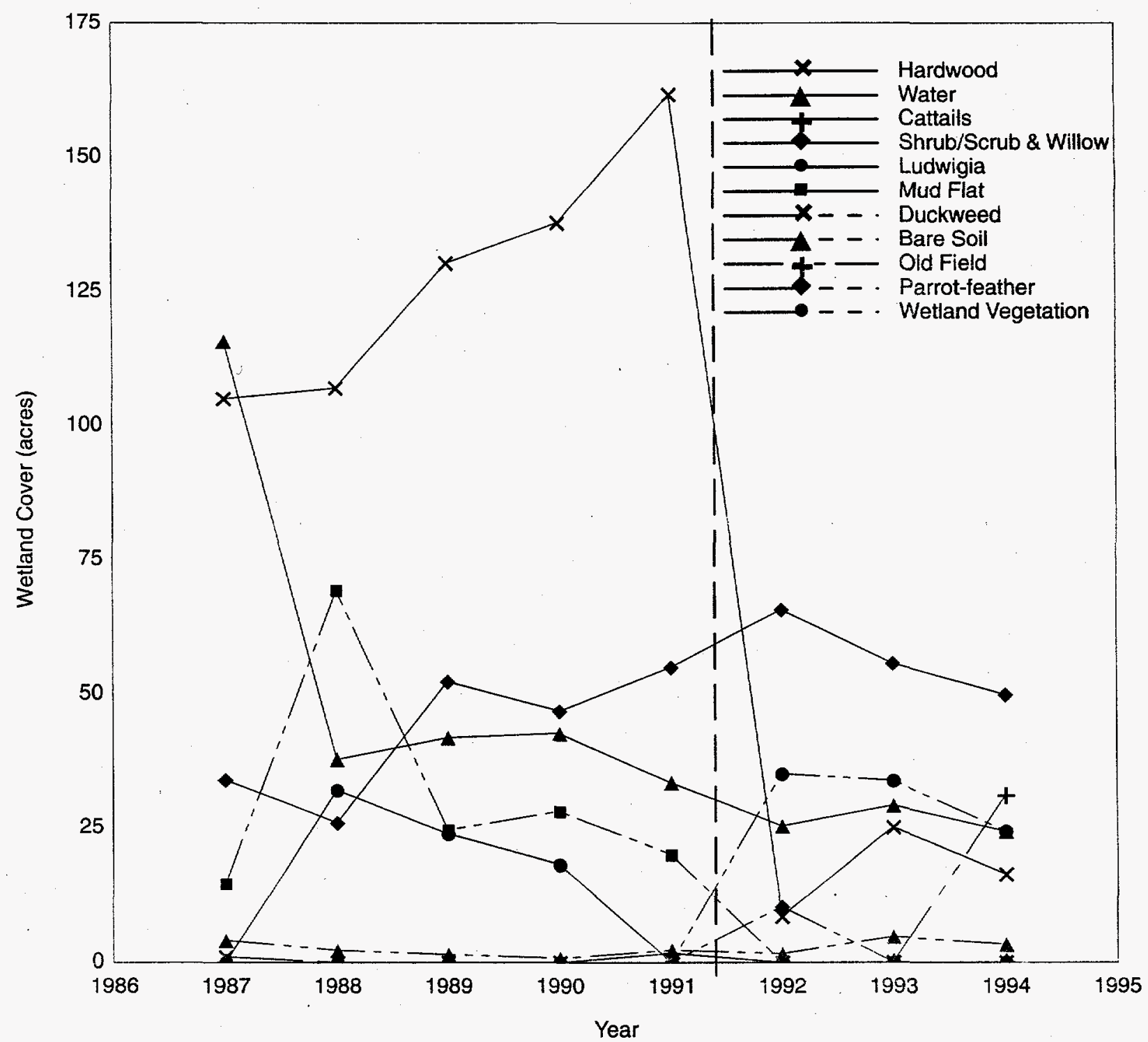

FIGURE 8. TRENDS FOR PEN BRANCH CORRIDOR WETLAND VEGETATION CLASSES FOR 1987 THROUGH 1994. ACreageS for only the lower corridor are shown to the right of the vertical dashed line.

estimates in the corridor since these two classes are sometimes difficult to separate spectrally (Blohm, 1995). The increase in old field species and the absence or small amounts of mud flat and bare soil classes in the corridor seem indicative of the normal water-flow rates recorded for that year.

\subsection{CONCLUSION}

Figures 8 and 9 summarize the trends in wetland class acreages for the Pen Branch corridor and delta for the years 1987 through 1994. The figures show that persistent and more permanent vegetation is replacing the 


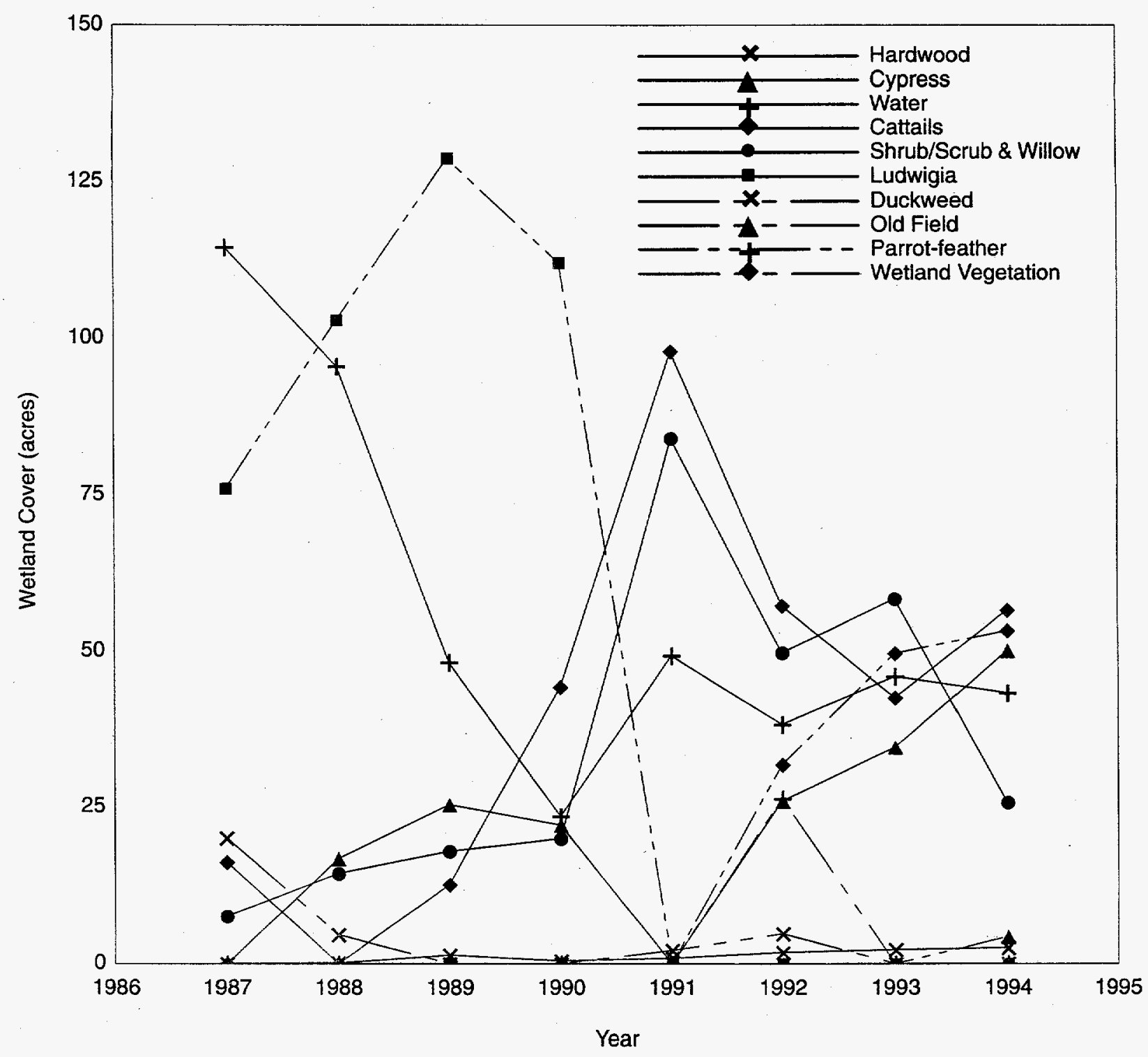

FIGURE 9. CLASS TRENDS FOR PEN BRANCH DELTA WETLAND VEGETATION CLASSES FOR 1987 THROUGH 1994

nonpersistent vegetation that survives during periods of flooding and thermal discharge (Mackey, 1990). This is illustrated by the decline of Ludwigia spp., duckweed, and parrot-feather class acreages and the increase in the shrub-scrub/willow class acreage in the lower corridor in 1992. More recently, herbicide treatments in the corridor have resulted in a decrease in the shrub-scrub/willow class acreage and subsequent increase in the old field class acreage. It is thought that the reduction in hardwood acreage in the corridor may be due to the eradication of the mature willow that may have been confused with the hardwood in previous years.

Drier conditions in the delta have resulted in increased acreage for hardwood, shrub-scrub/willow, persistent wetland vegetation, and cypress. Shrub-scrub/willow dominates the tail area of the delta. Ground observations indicate the initial invasion of young cypress near the boardwalk in the delta and tail areas. 
While MSS data acquisition dates are selected to optimize the spectral differentiation of wetland vegetation types, it is evident that other factors may influence classification results. When combined, the spatial resolution (7.6 meters) and the obtainable registration accuracies prohibit more precise species differentiation. Higher spatial resolution would support better classification results by resolving some of the confusion experienced in the study due to mixed pixel classes. Better ground control would provide more accurately measured ground reference points for improved registration accuracies. Additionally, an "early" or "late" spring season, the amount of rainfall, the timing or existence of reactor tests, and herbicide treatments play a very interactive role affecting vegetation regrowth in the Pen Branch corridor and delta. 


\section{COMPARISON OF CHANNEL WAVELENGTH AND SPECTRAL RESPONSE FOR SELECTED AIRBORNE SCANNER AND SATELLITE SYSTEMS}

\begin{tabular}{|c|c|c|}
\hline $\begin{array}{c}\text { Channel } \\
\text { Number }\end{array}$ & $\begin{array}{c}\text { Wavelength } \\
(\mu \mathrm{m})\end{array}$ & $\begin{array}{c}\text { Color } \\
\text { Spectrum }\end{array}$ \\
\hline 1 & $0.40-0.42$ & Near Ultraviolet \\
\hline 2 & $0.42-0.45$ & Violet / Blue \\
\hline 3 & $0.46-0.50$ & Blue / Green \\
\hline 4 & $0.50-0.55$ & Green \\
\hline 5 & $0.55-0.60$ & Green / Yellow \\
\hline 6 & $0.60-0.65$ & Orange / Red \\
\hline 7 & $0.65-0.70$ & Red \\
\hline 8 & $0.70-0.80$ & Near Infrared \\
\hline 9 & $0.81-0.94$ & Near Infrared \\
\hline 10 & $0.92-1.04$ & Near Infrared \\
\hline 11 & $8.5-10.9$ & Thermal Infrared \\
\hline 12 & $8.5-10.9$ & Thermal infrared \\
\hline \hline 12 & Alternate Configuration \\
\hline $1-10$ & & Empty \\
\hline 11 & $4.4-5.3$ & Mid - Infrared \\
\hline 12 & $8.2-11.0$ & Thermal - Infrared \\
\hline
\end{tabular}

\begin{tabular}{|c|c|c|}
\hline & \multicolumn{3}{|c|}{ Daedalus 1268 } \\
\hline $\begin{array}{c}\text { Channel } \\
\text { Number }\end{array}$ & $\begin{array}{c}\text { Wavelength } \\
\text { (m) }\end{array}$ & $\begin{array}{c}\text { Color } \\
\text { Spectrum }\end{array}$ \\
\hline 1 & $0.42-0.44$ & Violet / Blue \\
\hline 2 & $0.46-0.51$ & Blue / Green \\
\hline 3 & $0.52-0.59$ & Green / Yellow \\
\hline 4 & $0.59-0.62$ & Orange \\
\hline 5 & $0.62-0.67$ & Red \\
\hline 6 & $0.67-0.72$ & Near Infrared \\
\hline 7 & $0.73-0.85$ & Near Infrared \\
\hline 8 & $0.84-0.97$ & Near Infrared \\
\hline 9 & $1.59-1.79$ & Near Infrared \\
\hline 10 & $2.1-2.4$ & Near Infrared \\
\hline 11 & $8.28-10.67$ & Thermal Infrared \\
\hline 12 & $8.28-10.67$ & Thermal Infrared \\
\hline \hline & Alternate Configurnition \\
\hline $1-9$ & \multicolumn{3}{|c|}{ Same As Above } \\
\hline 10 & \multicolumn{3}{|c|}{ Empty } \\
\hline 11 & $3.16-5.20$ & Mid Infrared \\
\hline 12 & $8.28-10.67$ & Thermal Infrared \\
\hline & \multicolumn{3}{|c|}{} \\
\hline
\end{tabular}

\begin{tabular}{|c|c|c|}
\hline \multicolumn{3}{|c|}{ Landsat TM : } \\
\hline $\begin{array}{l}\text { Channel } \\
\text { Number }\end{array}$ & $\begin{array}{c}\text { Wavelength } \\
(\mu \mathrm{m})\end{array}$ & $\begin{array}{c}\text { Color } \\
\text { Spectrum }\end{array}$ \\
\hline 1 & $0.45-0.52$ & Blue / Green \\
\hline 2 & $0.52-0.60$ & Green / Yellow \\
\hline 3 & $0.63-0.69$ & Red \\
\hline 4 & $0.76-0.90$ & Near Infrared \\
\hline 5 & $1.55-1.75$ & Near Infrared \\
\hline 6 & $10.40-12.50$ & Thermal Infrared \\
\hline 7 & $2.08-2.35$ & Mid Infrared \\
\hline 2.2 & \multicolumn{2}{|c|}{ Landsat $4,5 \mathrm{MSS}$} \\
\hline 1 & $0.5-0.6$ & Green / Yellow \\
\hline 2 & $0.6-0.7$ & Orange / Red \\
\hline 3 & $0.7-0.8$ & Near Infrared \\
\hline 4 & $0.8-1.1$ & Near Infrared \\
\hline .2 .2 & SPOT: & 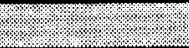 \\
\hline $\mathrm{XS}-1$ & $0.50-0.59$ & Green/ Yellow \\
\hline $\mathrm{XS}-2$ & $0.61-0.68$ & Orange / Red \\
\hline $\mathrm{XS}-3$ & $0.79-0.89$ & Near Infrared \\
\hline PAN - 1 & $0.51-0.73$ & Panchromatic \\
\hline
\end{tabular}




\section{APPENDIX B}

\section{DATES OF MSS DATA AND AERIAL AND GROUND PHOTOGRAPHY}

\begin{tabular}{|c|c|c|c|}
\hline & $\begin{array}{c}\text { Phenology } \\
\text { Dates }\end{array}$ & $\begin{array}{c}\text { Photography } \\
\text { Dates }\end{array}$ & $\begin{array}{l}\text { MSS } \\
\text { Dates }\end{array}$ \\
\hline 1992 April 03 & $\mathrm{x}$ & & \\
\hline 14 & $\mathrm{X}$ & & \\
\hline 15 & $\mathrm{X}$ & & \\
\hline 23 & $\mathrm{X}$ & $\mathrm{X}$ & $\mathrm{X}$ \\
\hline May 02 & & $\mathrm{X}$ & \\
\hline 04 & $\mathrm{X}$ & $\mathrm{X}$ & \\
\hline 23 & $\mathrm{X}$ & & \\
\hline 28 & $\mathrm{X}$ & & \\
\hline 1993 March 03 & $\mathrm{X}$ & & \\
\hline 16 & $\mathrm{X}$ & & \\
\hline April 15 & $\mathrm{X}$ & & \\
\hline 22 & & & $\mathrm{x}$ \\
\hline 30 & $\mathrm{X}$ & & \\
\hline May 13 & $\mathrm{X}$ & & \\
\hline 17 & $\therefore$ & $x$ & \\
\hline 19 & & $\mathrm{X}$ & \\
\hline 1994 March 29 & $\mathrm{X}$ & & \\
\hline April 14 & $x$ & $\mathrm{X}$ & \\
\hline 15 & & $\mathrm{x}$ & \\
\hline 17 & & $\mathrm{X}$ & \\
\hline 18 & & $\mathrm{x}$ & $\mathrm{X}$ \\
\hline 26 & $\mathrm{X}$ & & \\
\hline May 18 & $\mathrm{x}$ & & \\
\hline 20 & $\mathrm{X}$ & & \\
\hline
\end{tabular}




\section{REFERENCES}

Bennett, C.S., T.W. Cooney, K.H. Jones, and P.A. Drewes. Water Resources Data South Carolina: Water Year 1992, Water-Data Report SC-92-1. U.S. Geological Survey, 1993.

Bennett, C.S., T.W. Cooney, K.H. Jones, and P.A. Drewes. Water Resources Data South Carolina: Water Year 1993, Water-Data Report SC-93-1. U.S. Geological Survey, 1994.

Blohm, J.D. Pen Branch Stream Corridor and Delta Wetlands Change Assessment, Report No. EGG 11265-1013. EG\&G/EM, Las Vegas, Nevada, 1995.

Burkhalter, S.G. The Analysis of Human Impact and Change in the Savannah River Swamp Using Remote Sensing and Geographic Information Systems Technologies, Master's Thesis, University of South Carolina, Columbia, South Carolina, 1994.

Christel, L.M. Historical Wetlands Mapping and GIS Processing for the Savannah River Site Database, Report No. EGG 11265-1018. EG\&G/EM, Las Vegas, Nevada, 1994.

Christel, L.M., A.L. Guber. Land Cover Mapping and GIS Processing for the Savannah River Site Database, Report No. EGG 11265-1016. EG\&G/EM, Las Vegas, Nevada, 1994.

Christensen, E.J. Digital Change Detection: A Quantitative Evaluatian of Image Registration and Wetland Phenological Characteristics Using High Resolution Multispectral Scanner Data, Dissertation, University of South Carolina, Columbia, SC, 1987.

Christensen, E.J., M.E. Hodgson, J.R. Jensen, H.E. Mackey, Jr., and R.R. Sharitz. Pen Branch Delta Expansion, DPST-83-1087. Savannah River Laboratory, Aiken, South Carolina, p. 19, 1984.

Cooney, T.W, K.H. Jones, P.A. Drewes, J.W. Gissendanner, and B.W. Church. Water Resources Data South Carolina: Water Year 1994, Water-Data Report SC-94-1. U.S. Geological Survey, 1995.

Cowen, D.J., J.R. Jensen, P.J. Bresnehan, G. Ehler, D. Graves, X. Huang, C. Wiesner and H.E. Mackey, Jr. "The Design and Implementation of an Integrated Geographic Information System for Environmental Applications." Photogrammetric Engineering \& Remote Sensing, 61(11):1393-1404, 1995.

Dulohery, N., C. Bunton, C. Trettin, and W.H. McKee, Jr. Reforestation of the Pen Branch Corridor and Delta, Report No. WSRC-TR-96-0005,USDAFS, Charleston, South Carolina, Draft 1995.

Environmental Systems Research Institute, Incorporated. ARC/INFO Geographic Information System, Version 5.0.2, 1989.

Ezra, C.E., L.R. Tinney, and H.E. Mackey, Jr. Pen Branch and Four Mile Creek Land Cover Data Base, Savannah River Plant, Aiken, South Carolina, EG\&G/EM Letter Report No. DOE(ONS-SRL)-8605. EG\&G/EM, Las Vegas, Nevada, 1986.

Jensen, J.R., E.J. Christensen, and R.R. Sharitz. "Mapping of Thermally Altered Wetlands Using High Resolution Multispectral Scanner Data," Proceedings of American Society of Photogrammetry, May 22-27, 1983, Seattle, WA, pp. 318-336, 1983.

Jensen, J.R., E.W. Ramsey, H.E. Mackey, Jr., E.J. Christensen, and R.R. Sharitz. "Inland Wetland Change Detection Using Aircraft MSS Data." Photogrammetric Engineering and Remote Sensing, 53(5):521-529, 1987. 
Jensen, J.R., M.E. Hodgson, E.J. Christensen, H.E. Mackey, Jr., L.R. Tinney, and R.R. Sharitz. "Remote Sensing of Inland Wetlands: A Multispectral Approach." Photogrammetric Engineering and Remote Sensing, 52(1):87-100, 1986.

Lillesand, T.M., R.W. Kiefer. Remote Sensing and Image Intrepretation. 2d ed., Wiley, New York, New York, 1987.

Mackey, H.E. "Monitoring Seasonal and Annual Wetland Changes in a Freshwater Marsh with SPOT HRV Data," Proceedings of 56th Annual Meeting of American Society of Photogrammetry and Remote Sensing, Denver, Colorado, 4:283-292, 1990.

Mackey, H.E. "Six Years of Monitoring Annual Changes in a Freshwater Marsh with SPOT HRV Data," Proceedings of 59th Annual Meeting of American Society of Photogrammetry and Remote Sensing, New Orleans, Louisiana, 2:222-229, 1993.

PCI Inc. EASI PACE, Version 5. Richmond Hill, Ontario, Canada, 1992.

Ruby, C.H., P.J. Reinhardt, and C.L. Reel. Sedimentation and Erosion Trends of the Savannah River Plant Reactor Discharge Creeks, Report No. RPI/R/81/7/24-22. Research Planning Institute, Inc., Columbia, South Carolina, 1981.

Tinney, L.R., C.E. Ezra, and H.E. Mackey, Jr. Stream Corridor and Delta Wetlands Change Assessments, Savannah River Plant, Aiken, South Carolina, EG\&G/EM Letter Report No. DOE(ONS-SRL)-8604. EG\&G/EM, Las Vegas, Nevada, 1986.

Tinney, L.R., S.B. Brewster, Jr. "SPICE - Scatterplot Partitioning for Image Classification and Evaluation," Proceedings of the Symposium on Machine Processing of Remotely Sensed Data, Purdue University, West Lafayette, Indiana, 1984.

Wike, L.D., R.W. Shipley, J.A. Bowers, A.L. Bryan, C.L. Cummins, B.R. del Carmen, G.P. Friday, H.E. Mackey, Jr., J.J. Mayer, E.A. Nelson, M.H. Paller, V.A. Rogers, L. Specht, and E.W. Wilde. SRS Ecology Environmental Information Document, Report No. WSRC-TR-93-496. Savannah River Site, Aiken, South Carolina, 1994. 
DOE/DP
L. E. Gordon-Hagerty
O. W. Taylor

(1)

(1)

\section{SRS/WSRC}

J. B. Gladden

H. E. Mackey

D. B. Moore-Shedrow

E. A. Nelson

(1)

(1)

(2)

DOE/HQ

OSTI

(25)

\section{BN}

DOENN

M. R. Dockter

(1)

Public Reading Room

TIO

TIRC

$\begin{array}{ll}\text { L. M. Christel } & \text { LVAO } \\ \text { C. E. Ezra } & \text { LVAO } \\ \text { P. P. Guss } & \text { WAMO } \\ \text { R. E. Kelley } & \text { LVAO } \\ \text { T. E. Richardson } & \text { LVAO } \\ \text { L. R. Tinney } & \text { LVAO }\end{array}$

\section{LIBRARIES}

(2)
E. C. Goodson
A. B. Gould, Jr.

(2)

RSL

(30) 